\title{
DIAGNÓSTICO FÍSICO-CONSERVACIONISTA - DFC DA BACIA DO RIO MARRECAS - SUDOESTE DO PARANÁ

\author{
ELIANE REGINA FERRETI*
}

\author{
DISSERTAÇÃO DE MESTRADO - Programa de Pós-Graduação em Geologia - UFPR \\ DATA DE DEFESA: 07/12/98
}

A questão ambiental (re)discute formas de apropriação dos recursos naturais, pois os processos que alteram o ambiente tem permanecido no manto da modernidade e produção de mercadoria, gerando alteração da qualidade desses recursos, através da poluição/ esgotamento de suas potencialidades. A ausência de políticas adequadas, quanto ao planejamento dos recursos naturais, tem produzidos erros (muitos irrevesíveis), induzindo a degradação ambiental. Isso ocorre, na maioria das vezes, porque os governos cuidam dos fatores solo, água, fauna e flora separadamente. Essa visão reducionista, torna-se problemática quando utilizada para tomar-se decisões. Planejar para desenvolver é manejar o ambiente, visando a melhoria da qualidade de vida do ser humano. Cada vez mais, sente-se necessidade de estudos e planejamentos do ambiente, que sejam abragentes e capazes de avaliar a degradação crescente dos recursos naturais renováveis no Brasil. A bacia hidrográfica é reconhecida mundialmente como a melhor unidade para o manejo dos recursos naturais. Assim, uma metodologia para o diagnóstico da situação real dos recursos naturais numa bacia, passa a ser um instrumento necessário para a preservação e gerenciamento destes recursos. Neste sentido, o DFC da bacia do rio Marrecas - sudoeste do Paraná, determinou o seu potencial de degradação ambiental, a partir de fatores naturais pré-definidos visando, especialmente, o planejamento e manejo dos recursos, com vistas à sua preservação. Este estudo, baseia-se na Metodologia para DFC de Bacias Hidrográficas, desenvolvida pelo CIDIAT/MARNR, da
Venezuela e, na proposta desenvolvida por BELTRAME (1990), na bacia do Rio do Cedro, em Brusque, SC. A bacia do rio Marrecas foi subdividida em quatro setores $(A, B, C$ e $D)$, para posterior comparação dos estudos ambientais de cada setor. A metodologia parte de definição de sete parâmetros: grau de semelhança entre a cobertura vegetal original e atual; grau de proteção fornecido ao solo pela cobertura vegetal atual; declividade média; erosividade da chuva; potencial erosivo dos solos; densidade de drenagem e o balanço hídrico. Para o desenvolvimento do DFC e confecção de onze mapas temáticos em escala 1: 50.000 da bacia, foram utilizados fotografias aéreas; imagem multiespectral digital do satétile LANDSAT TM-5; dados de geologia, relevo, solos, uso do solo; dados de precipitação e temperatura e referências bibliográficas. Os parâmetros identificados foram expressos de forma numérica, através de uma fórmula descritiva, que estabeleceu o risco de degradação dos setores da bacia, possibilitando a análise qualitativa quanto a preservação desses recursos. O estado ambiental da bacia do rio Marrecas, identificado após aplicação do diagnóstico físico-conservacionista, é preocupante. O DFC da bacia do rio Marrecas constitui um subsídio básico para trabalhos a nível de extensão rural e/ou projetos que visem a recuperação ambiental da área, pois fornece indicativos para a racionalização do uso e manejo dos recursos da bacia. A metodologia para DFC adaptada e aplicada na bacia do rio Marrecas, mostrou-se adequada para de ser utilizada em outras bacias hidrográficas.

*E-mail: ferrettier@milenio.com.br 